\title{
The Crucible of Islam
}

G.W. Bowersock

Cambridge: Harvard University Press, 2017, 220 sayfa.

ISBN 9780674057760

Erken İslam tarihi araştırmalarına dair gün geçtikçe zenginleşen ikincil literatüre, Bowersock'un son kitabı The Crucible of Islam ile (İslam'ın potası) önemli bir katkı daha sağlandı. Erken İslam tarihinin mevcut ikincil kaynaklarından farklı olarak, kitabının içeriğini, Ebrehe krallı̆̆ının hakimiyetinden, Kubbetüssahra’nın inşasına kadar devam eden süreçle sınırlandıran Bowersock, ele aldığı olağan dışı başlıklarıyla okuyucularına diğer kaynaklardan farklı bir değerlendirme çerçevesi çiziyor. Seçtiği bu başlıklarla konuyu, Etiyopya, Filistin, Bizans ve Sâsânîler özelinde Geç Antikçağ’dan, İslam’ın ilerleme sürecine doğru ele alan yazar, İslam’ın yayılış sürecindeki bütün önemli dinamikleri, İslam’ın içine doğmuş olduğu tarihsel ve coğrafî arka plan temelinde ele alıyor. Bowersock, Empires in Collision ve Throne of Adulis adl önemli iki diğer kitabında da genel olarak İslam öncesi dünyayı tasvir etmeye özel olarak da Etiyopya ve Arabistan bölgesinin sosyopolitik dengelerine odaklansa da, diğerlerinden farklı olarak The Crucible of Islam'da İslam'ın tarihsel gelişimini kitabının merkezine alıyor ve bu dengeleri bu İslam’ın gelişiminin en büyük parçası olarak inceliyor. Bu bağlamda gayesini kitabının en başında açıklayan Bowersock, İslam’ın doğuşunu ele alan literatüre dair genel bir tarama yaptıktan sonra, çalışmasını mevcut literatüre yeni bir ekleme yapma niyetiyle ortaya koymadığını; bundan ziyade dönemin kaotik şartlarının İslam’ın oluşumunu ve gelişimini nasıl mümkün hale getirdiğini anlamaya katkı sağlamak için yaptığını ifade ediyor. Bu sebeple, kitabın öncelikli hedefinin, İslam'ın gelişimini daha iyi anlamak adına Yahudilik, Hristiyanlık ve paganlığın yaygın olduğu Arap yarımadasının sosyal ve kültürel çevresini tanımlamak olduğunu söylüyor.

Bowersock, belirli bir hedef kitlesi tanımlamamış olsa da, The Crucible of Islam, bütün erken İslam tarihi okuyucularına, İslam tarihinin oluşum ve gelişim aşamalarını ele alan diğer ikincil kaynaklara nazaran daha kapsaml1 bir perspektif sunuyor. Bununla birlikte herhangi bir metodolojiye bağlı olma çabasında olmadığını belirten Bowersock, çizgisinin ne bütün kaynakları sorgusuz kabul etmek ne de onları tamamen göz ardı etmek olduğunu söyleyerek, sahip olduğu tek yöntemin kritik sebeplendirme ve sorgulama 
olduğunun altını çiziyor. Bu vurgusu da yine, kitabı muadillerinden farklı bir konuma taşıyor.

Kitabın içeriği ayrıntılı incelendiğinde, Bowersock'un belirli kısımlarda sorgulayıcı dilini başarılı bir şekilde kullandığı görülüyor olsa da, kendini yer yer tekrar ettiği farkediliyor. Bununla birlikte İslam’nn gelişimini tarihsel bağlamı temelinden inceleme hedefini kitap boyunca başarılı bir şekilde takip eden Bowersock, kitabının "The Arabian Kingdom of Abraha" adlı ilk bölümüne, Arap yarımadasının İslam öncesi sosyopolitik vaziyetini detaylıca tasvir etmek ve bu sayede ileride ele alacağı Etiyopya ve Arabistan ilişkisinin Arap yarımadasında oluşturduğu sosyokültürel etkilere güçlü bir referans sağlamak üzere Ebrehe’nin krallığı döneminde yaşanan önemli denge değişimlerini anlatarak başlıyor. "Arab Paganism in Late Antiquity" başlıklı ikinci bölüme geldiğinde Bowersock, epistemolojik bağlamda paganizmi kategorilere ayırarak, tek tanrı etrafında şekillenmiş ve bu çerçeve içerisinde dönüşmüş politeizmin esasında pagan motenizmi olarak tanımlanabileceğini söyler. Kitabın bir sonraki "Late Antique Mecca" adlı bölümünde ise, pagan monetizmi olarak kabul edebileceğimiz Helen ve Fars kültüründen etkilenmiş Arap putperestliğinin de bahsini ettiği türde bir pagan monetizmi olarak gelişmiş olabileceğini iddia eder. Bu çıkarımın ve çevresinde sunduğu örneklerin, Bowersock'un kitaptaki en doyurucu ve rasyonel analizi olduğu söylenebilir. Sonraki iki bölüm olan "Ethiopia and Arabia" ve "Persians in Jerusalem" adlı kısımlarda Bowersock, İslam’ın doğuşunu ve gelişim sürecini doğrudan bölge üzerinde yüzyıllardır hakimiyet mücadelesi güden Roma ve Sâsânî kültürlerinin ve Etiyopya siyaseti temelinde değişen yerel dengelerin sosyal ve kültürel etkisi altında ele alıyor.

"Muhammad and Medina" adlı bir sonraki bölümde, bir önceki bölümdeki iddiasını güçlendiren Bowersock, İslam’’n gelişim sürecinin en başında Habeşistan’a yapılan ilk hicret ve müslümanların oraya kabulü, Medine’ye yapılan hicret ve Evs ve Hazreç kabilelerinin İslam’ı seçmesi gibi bütün ayrıntıları bu sosyokültürel çerçeveden inceleyerek, İslam’ı kabul edenlerin İslam’ kabul etmeleri başta olmak üzere bütün bu değişim ve dönüşümlerdeki en büyük saikin, kendilerine kadar süregelmiş bütün bu etkilerin bir neticesi olduğunu belirtiyor. Bowerscok’a göre tek tanrı inancının bölgede yaşayan hıristiyanlardan ve yahudilerden dolayı özellikle Medine civarı için zaten yaygın bir inanç türü olması, moneteist bir din olan İslamı̉n toplumda kabulünü ve bütün bu gelişmelerin meydana gelmesini daha da kolaylaştırıyor. Ancak Bowersock'un yaptığı bu matematiksel sebep-sonuç vurgusu tarihsel bir çıkarım adına fazlasıyla tek yönlü ve indirgemeci değil mi? Çünkü tarihsel bir olayın sebebini yalnızca belirli saiklerle sınırlamak, tarihi doğru 
anlama çabasını imkânsız kılıyor. Ayrıca her ne kadar İslamın, hem Arap putperestliğinden hem de bölgede etkisi görülen diğer tek tanrılı dinlerden ayırım noktalarını detaylıca tasvir ediyor olsa da, Bowersock'un İslam’ tam bu noktada, yalancı peygamber Müseylime’yi temel referansı alarak birçok peygamberlik iddiasının aynı anda bölgede hüküm sürdüğünü iddia ettiği bir devirde, köklerini bölgedeki tek tanrıcı dinlerin ortak noktası olan $\mathrm{Hz}$. İbrâhim’e dayandırdığı için bütün diğer iddialar arasında mücadeleyi kazanabilmiş ve dolayısıyla bölgede dinî otoritesini kurabilmiş bir tür pagan Arap monetizmi olarak yorumlaması oldukça yargısal ve temelsiz kalıyor. Zira, okuyucularına İslam’ın doğduğu ilk devir olan Mekke'de -en azından İslam’nn doğduğu andan itibaren- bahsini ettiği şekilde bir peygamberlik mücadelesinin tarihsel varlığına dair bir kanıt sunamıyor. Bununla birlikte, yalnızca -Müseylime gibi- Hz. Peygamber'e vahiy gelmeye başlamasından çok sonra peygamberlik iddiasında bulunmuş kişileri referans alarak öncesinde de bu iddiada bulunmuş birçok kişinin var olmuş olabileceğini iddia etmesi ve bu bağlamda muhtemel peygamberlik iddiasının sahipleri arasında Hz. Peygamber'in ilk kişi olup olmadığının asla bilinemeyeceğini söylemesi, argümanının temelsizliğini ortaya koymaya yetiyor. Bowerscok’un, kitabın başından bu yana seçtiği spesifik noktalar ve onların etrafında yaptığı çıkarımlarının dolaylı olarak kendisine vardığı ve ilerleyen bölümlerin neredeyse tamamında kendini açıkça gösteren bu argüman, bana kalırsa kitabın en büyük kırılma noktasını oluşturuyor.

Bununla birlikte, "Interregnum of the Four Caliphs" adlı bir sonraki bölümde Hz. Peygamber' in, birçok etkili lider gibi, kendisinden sonra gelenler için geride iyi bir hazırlık bırakamamış olduğunu ve yeni gelenlerin -özellikle dört halifeyi kastederek- onun başarısına ulaşmak adına mücadele vermiş olmalarının onun başlattığı bu hareketi oldukça tehlikeli bir boyuta taşıdığını iddia etmesi bir başka yargısal ve temelsiz iddialarından biridir. Zira ilk iddiasında olduğu gibi bunun için de sağlam bir kanıt sunmamakla birlikte oldukça öznel bir ifadeyle meseleyi açıklayarak, her iki iddiasında da İslam’’ bir dinden çok, propagandist bir hareket mesabesinde ele alması rasyonel yaklaşımdan uzak olduğu kadar oldukça saldırgandır. "The New Dispensation” ve "Dome of Rock" adlı son iki bölümünde ise dört halife sonrası siyasî gelişmeler, iç savaşlar, yeni fetihler ve Arabistan dışında İslam’ın yayılış sürecini kısa kısa ele alan Bowersock, her ne kadar bu kısımlarda diğer bölümlerden daha fazla betimlemeci bir üslup kullansa da, İslam’ın doğuşu ve gelişmesi evresinde yaptığı açıklamalarda sahip olduğu tekdüze ve indirgemeci yaklaşım tarzını burada da yansıtarak, söz konusu gelişmeleri çoğunlukla yine bölgede o güne kadar hakim olmuş siyasî ve sosyokültürel dinamiklerin etkisi altında 
inceliyor. Ayrıca, "Dome of Rock" şeklinde spesifik bir isimlendirmeye gittiği son bölümde, Kubbetüssahra’nın inşasını, bölgedeki diğer dinlere -özellikle Yahudilik- İslam’ın bundan sonra herhangi bir hayat hakkı tanımadığını ilan etmek için gösterdiği bir üstünlük mücadelesi olarak değerlendirmesi söz konusu saldırgan yaklaşımını daha da gözler önüne seriyor.

Ayrı bir sonuç bölümüne gitmeden, kitabı boyunca sahip olduğu bütün iddialarını yine bu bölümde toparlayan Bowersock'un, yine aynı yaklaşım tarzıyla, Hz. Peygamber’in İslam adı altında oluşturduğu geleneğin, -özellikle Kubbetüssahrảnın inşasından itibaren- Hıristiyanlık ve Yahudilik ile kıyasen birçok uyumsuz doktrin ve gelenekle dolu bir potaya dönüştügünü ve bu derece uyumsuzlukların İslam olarak hâlâ devam ediyor olmasının çok şaşırtıcı olduğunu iddia etmesi kitap boyunca takip ettiği ana akım oryantalist tutumunu özetler niteliktedir. Bu bağlamda ne yazık ki en başta yaptığ literatür taramasının hemen ardından İslam tarihi konusundaki yaygın Batı literatürüne genel bir atıfta bulunarak, müslüman olmayanların İslam’ı sorgusuz reddetmelerinin ve yalnızca hıristiyan ve yahudi kaynaklarına bakarak İslam’ı anlamaya çalışmalarının doğru olmadığını belirtecek kadar çok yönlü bir yaklaşım sahibi olsa da, Bowersock'un söz konusu tutumunun hem bahsini ettiği kritik değerlendirme metodolojisi hem de kitabında güttüğünü ifade ettiği hedefi itibariyle, kendisini konumlandırdığ çizgi ile oldukça çeliştiğini söyleyebilirim. Her ne kadar diğer eserlerinde de yer yer yargısal dili göze çarpiyor olsa da, Bowersock'un bu kitapta sahip olduğunu iddia ettiği revizyonist ve kritik bakış açısının tam aksine, saldırgan ve oryantalist söyleminin kitabın tamamına bu derece nüfuz etmiş olması oldukça sorunludur. Bu itibarla, Bowersock'un The Crucible of Islam ile okuyucularını büyük düzeyde hayal kırıklığına uğrattığını düşünüyorum.

Tuğba Türkoğlu, Doktora Öğrencisi İstanbul Medeniyet Üniversitesi Tarih Bölümü

ORCID 0000-0001-6997-1727

DOI 10.26570/isad.650335 